\title{
Karolina Rokicka-Murszewska
}

Uniwersytet Mikołaja Kopernika, Toruń

krm@umk.pl

ORCID: https://orcid.org/0000-0001-5402-4137

\section{Kara pieniężna za niewydanie decyzji o ustaleniu lokalizacji inwestycji celu publicznego w ustawowym terminie - wybrane problemy}

http://dx.doi.org/10.12775/SIT.2019.010

Niniejsze opracowanie zostało poświęcone karze pieniężnej wymierzanej organowi administracyjnemu wydającemu decyzję o ustaleniu lokalizacji inwestycji celu publicznego ${ }^{1} \mathrm{z}$ przekroczeniem terminu określonego $\mathrm{w}$ art. 51 ust. 2 Ustawy $\mathrm{z}$ dnia 27 marca 2003 r. o planowaniu i zagospodarowaniu przestrzennym² ${ }^{2}$. Według projektodawcy celem wprowadzenia kary do polskiego systemu prawnego było przyśpieszenie postępowania w sprawie wydania decyzji u.l.i.c.p. i skrócenie procesu inwestycyjnego ${ }^{3}$. W związku z tym ustawodawca zastrzegł, że przypadku niewydania tej decyzji w terminie 65 dni od dnia złożenia wniosku organ wyższego stopnia

\footnotetext{
${ }^{1}$ Dalej również jako: decyzja u.l.i.c.p.

2 Tekst jednolity: Dz.U. z 2018 r. poz. 1945 ze zm., dalej: u.p.z.p.

${ }^{3}$ Uzasadnienie do projektu ustawy o wspieraniu rozwoju usług i sieci telekomunikacyjnych, druk sejmowy $\mathrm{nr}$ 2546, http://orka.sejm.gov.pl/Druki6ka.nsf/0/E66946D6693A2B2FC125767F0047BEFD/\$file/2546.pdf (dostęp: 22.03.2019 r.).
} 
w drodze postanowienia, na które przysługuje zażalenie, wymierza organowi prowadzącemu postępowanie karę pieniężną w wysokości 500 zł za każdy dzień zwłoki.

Należy zauważyć, że nie tylko w u.p.z.p. przewidziano tego rodzaju kary nakładane na organ. Analogiczne kary pieniężne ustawodawca zastrzega w przypadku, gdy organ administracji architektoniczno-budowlanej nie wyda decyzji w sprawie pozwolenia na budowę w ciągu 65 dni (45 dni, jeśli wniosek dotyczył inwestycji kolejowej) ${ }^{4}$ lub właściwy zarządca drogi nie wyda w formie decyzji zezwolenia na lokalizowanie w pasie drogowym obiektów budowlanych lub urządzeń niezwiązanych z potrzebami zarządzania drogami lub potrzebami ruchu drogowego oraz reklam w ciągu 65 dni (45 dni, jeśli decyzja dotyczy infrastruktury telekomunikacyjnej) ${ }^{5}$.

Mimo to ten swoistego rodzaju środek dyscyplinujący, jakim jest kara pieniężna za niewydanie decyzji w ustawowym terminie, nie był dotychczas przedmiotem szczególnego zainteresowania doktryny ${ }^{6}$. Być może wynika to z faktu, że zazwyczaj uwaga skupia się raczej na administracyjnych karach pieniężnych, a więc sankcjach o charakterze pieniężnym, nakładanych przez organ administracji publicznej w drodze decyzji, w następstwie naruszenia prawa polegającego na niedopełnieniu obowiązku albo naruszeniu zakazu ciążącego na osobie fizycznej, osobie prawnej albo jednostce organizacyjnej nieposiadającej osobowości prawnej (art. 189b Ustawy z dnia 14 czerwca 1960 r. - Kodeks postępowania administracyjnego) $^{7}$. Powyższe nie oznacza jednak, że kara, o której mowa w art. 51 ust. 2 u.p.z.p., oraz administracyjne kary pieniężne nie mają ze

${ }^{4}$ Art. 35 ust. 6 Ustawy z dnia 7 lipca 1994 r. - Prawo budowlane (tekst jednolity: Dz.U. z 2018 r. poz. 1202 ze zm., dalej: Pr. bud.).

${ }^{5}$ Art. 39 ust. 3b Ustawy z 21 marca 1985 r. o drogach publicznych (tekst jednolity: Dz.U. z 2018 r. poz. 2068 ze zm., dalej: u.d.p.).

${ }^{6}$ W szczególności, jeśli chodzi o decyzję u.l.i.c.p. W odniesieniu do pozwolenia na budowę por. A. Kosicki, Kara za nieterminowe wydanie pozwolenia na budowę, „Nieruchomości” 2011, nr 3, dodatek: „Prawo Budowlane w Orzecznictwie Sądów Administracyjnych"; A. Plucińska-Filipowicz, Kara za zwłokę $w$ wydaniu pozwolenia na budowę, „Nieruchomości” 2011, nr 3, dodatek: „Prawo Budowlane w Orzecznictwie Sądów Administracyjnych”.

7 Tekst jednolity: Dz.U. z 2018 r. poz. 2096 ze zm., dalej: k.p.a. 
sobą nic wspólnego. Należy bez wątpienia rozważyć wzajemne zależności pomiędzy karą pieniężną za opóźnienie w wydaniu decyzji u.l.i.c.p. a regulacjami zawartymi w k.p.a., nie tylko w kontekście zasad nakładania kar pieniężnych, ale również - kwestii terminów i sposobu ich obliczania. Szczegółowym przedmiotem rozważań będzie także charakter prawny przedmiotowej kary pieniężnej, organ wyższego stopnia, który ją wymierza, oraz swoistego rodzaju „przedawnienie” kary.

\section{Decyzja o ustaleniu lokalizacji inwestycji celu publicznego}

Podstawowymi instrumentami w systemie zagospodarowania przestrzennego kraju są miejscowy plan zagospodarowania przestrzennego ${ }^{8}$ oraz studium uwarunkowań i kierunków zagospodarowania przestrzennego ${ }^{9}$. Zarówno plan miejscowy, jak i studium są uchwalane w trybie tzw. procedury planistycznej, będącej sekwencją pewnych czynności, jakie podejmują organy, aby doprowadzić do uchwalenia wskazanych aktów, a do tego bez wątpienia procesem czasochłonnym i długotrwałym ${ }^{10}$. Ustawodawca nie zastrzegł obligatoryjności uchwalania planu miejscowego na terenie gmin. Wyrażony expressis verbis obowiązek sporządzenia planu miejscowego dotyczy jedynie przypadków, o których mowa w przepisach odrębnych (art. 14 ust. 7 u.p.z.p.), nie wskazuje się jednak w u.p.z.p., o jakie przepisy dokładnie chodzi ${ }^{11}$. Obowiązkowo sporządza się jedynie studium uwarunkowań, przy czym nie jest to akt prawa miejscowego - nie ma więc charakteru aktu prawnego powszechnie obowiązującego, a jego funkcją są jedynie określanie polityki prze-

${ }^{8}$ Dalej również jako: plan miejscowy.

${ }^{9}$ Dalej również jako: studium.

10 Por. K. Rokicka, Uchwały rady gminy $w$ procedurze planistycznej - wybrane problemy, "Samorząd Terytorialny” 2015, nr 11, s. 15; K. Rokicka-Murszewska, w: Specustawa mieszkaniowa. Komentarz, red. A. Jakubowski, Warszawa 2019, s. 136.

${ }_{11}$ Zob. eadem, Administracyjnoprawne aspekty opłaty planistycznej, Torun 2019, s. 48 wraz z przywołanymi tam przykładami oraz literaturą. 
strzennej gminy oraz wskazanie lokalnych zasad zagospodarowania przestrzennego. Taki stan prawny doprowadził do niewielkiego, mimo upływu ponad 15 lat od wejścia w życie ustawy, pokrycia terytorium kraju planami miejscowymi. W sytuacji braku planu miejscowego na danym terenie, zgodnie $z$ dyspozycją art. 6 ust. 2 pkt 1 u.p.z.p., określenie sposobów zagospodarowania i warunków zabudowy terenu następuje w drodze jednej $z$ dwóch rodzajów decyzji o warunkach zabudowy i zagospodarowania terenu ${ }^{12}-$ decyzji o warunkach zabudowy oraz decyzji o ustaleniu lokalizacji inwestycji celu publicznego.

Wskazać należy, że - zgodnie $z$ definicją zawartą w art. 2 pkt 5 u.p.z.p. - przez inwestycję celu publicznego rozumie się „działania o znaczeniu lokalnym (gminnym) i ponadlokalnym (powiatowym, wojewódzkim i krajowym), a także krajowym (obejmującym również inwestycje międzynarodowe i ponadregionalne) oraz metropolitalnym (obejmującym obszar metropolitalny) bez względu na status podmiotu podejmującego te działania oraz źródła ich finansowania”. Działania te stanowią realizację celów, o których mowa w art. 6 Ustawy z dnia 21 sierpnia 1997 r. o gospodarce nieruchomościami ${ }^{13}$. Chodzi m.in. o budowę dróg publicznych, rowerowych i wodnych, urządzeń transportu publicznego i łączności publicznej, wydzielenie gruntów pod linie kolejowe oraz ich budowę i utrzymanie czy też zakładanie i utrzymywanie cmentarzy.

Decyzja u.1.i.c.p. jest wydawana na wniosek inwestora po przeprowadzeniu postępowania administracyjnego przez właściwy organ. W zależności od charakteru inwestycji różnie zostały określone organy właściwe do jej wydania. Co do zasady są to wójt, burmistrz albo prezydent miasta (w przypadku inwestycji o znaczeniu krajowym i wojewódzkim - w uzgodnieniu z marszałkiem województwa). Natomiast dla inwestycji celu publicznego na terenach zamkniętych decyzje wydaje wojewoda. Definiując „tereny zamknięte” w art. 2 pkt 11 u.p.z.p., ustawodawca odsyła nas do art. 2 pkt 9 Ustawy z dnia 17 maja 1989 r. - Prawo geodezyjne i kartograficzne ${ }^{14}$, gdzie

12 Dalej również jako: decyzje lokalizacyjne.

${ }^{13}$ Tekst jednolity: Dz.U. z 2018 r. poz. 2204 ze zm., dalej: u.g.n.

14 Tekst jednolity: Dz.U. z 2019 r. poz. 725 ze zm. 
za „tereny zamknięte” uznaje się „tereny o charakterze zastrzeżonym ze względu na obronność i bezpieczeństwo państwa, określone przez właściwych ministrów i kierowników urzędów centralnych”. Odstąpienie od właściwości organów gminy (samorządowych) w sprawach decyzji u.l.i.c.p. na terenach zamkniętych na rzecz wojewody (organu terenowej administracji rządowej) wydaje się jednak uzasadnione. Argumentem za wprowadzeniem tego rodzaju wyjątku jest specyfika terenów zamkniętych, wyodrębnionych ze względu na ważny interes państwa i konieczność pozostawienia decyzji dotyczących gospodarki przestrzennej na ich terenie we właściwości organów administracji rządowej ${ }^{15}$, choć - jak zostanie to wykazane w dalszej części artykułu - kompetencja wojewody do wydawania decyzji w I instancji wywołuje niemałe problemy na tle regulacji art. 51 ust. 2 a u.p.z.p.

\section{Charakter prawny kary pieniężnej, o której mowa w art. 51 ust. 2 u.p.z.p.}

Karę pieniężną za niewydanie decyzji u.1.i.c.p. w ustawowym terminie należy zaliczyć do szerszej grupy kar administracyjnych, sytuowanych w kategorii sankcji prawnych stosowanych w działalności organów administracji - tzw. sankcji administracyjnych ${ }^{16}$. Sankcje wymierzane w postępowaniu administracyjnym (podobnie jak określone sankcje w prawie karnym, wykroczeń czy w postępowaniach dyscyplinarnych) można sklasyfikować jako sankcje represyjne - dolegliwości stanowiące odpłatę za zachowanie niezgodne $z$ nakazami lub zakazami wynikającymi z przepisów prawa, których istota sprowadza się do pozbawienia danego podmiotu określonego dobra ${ }^{17}$. Jak słusznie zauważa Mirosław Wincenciak,

15 Zob. Planowanie i zagospodarowanie przestrzenne. Komentarz, red. Z. Niewiadomski, Warszawa 2018, komentarz do art. 51, Nb 3.

${ }^{16}$ Zob. na ten temat np. H. Nowicki, Sankcje administracyjne, w: System prawa administracyjnego, tom 7: Prawo administracyjne materialne, red. R. Hauser, Z. Niewiadomski, A. Wróbel, Warszawa 2012, s. 619 i nast.

17 Por. M. Wincenciak, Sankcje $w$ prawie administracyjnym i procedura ich wymierzania, Warszawa 2008, s. 17. 
„w prawie administracyjnym stosuje się niekiedy pewne rodzaje sankcji wobec organów administracyjnych za naruszenia popełnione wieloma czynnościami lub czynnościami powtarzającymi się mniej lub bardziej systematycznie w pewnym czasie [...]"18.

W pierwszej kolejności należy podkreślić prewencyjny charakter kary, o której mowa w art. 51 ust. 2 u.p.z.p. Jej wysokość ustawodawca określa w stawce dziennej (500 zł), nakazując obciążenie organu pozostającego w zwłoce jej wielokrotnością w zależności od czasu uchybienia terminowi do wydania decyzji. Takie uregulowanie wymusza na organie wydawanie kolejnych decyzji w ustawowo gwarantowanym terminie ${ }^{19}$. Zapobieżenie zwłoce należy uznać za ratio legis, które legło u podstaw uregulowania instytucji kary w u.p.z.p. Jednocześnie jednak tak wysoka kara może być postrzegana jako represja wobec podmiotu, który zostanie nią obciążony. Nie będzie ona stanowić nadmiernego obciążenia dla budżetu jednostki samorządu terytorialnego wyłącznie w tych przypadkach, kiedy opóźnienie będzie niewielkie i wyniesie kilka dni. Ponadto w kontekście represyjnego charakteru - należy wskazać, że z jednej strony wysokość sankcji nie jest zależna w żaden sposób od tego, czy wnioskodawca poniósł jakąkolwiek szkodę w związku z opóźnieniem w wydaniu decyzji, z drugiej zaś - zasila ona budżet państwa, nie jest żadną rekompensatą dla podmiotu potencjalnie pokrzywdzonego czasem oczekiwania. Nie bez znaczenia jest również to, że w sytuacji błędnego obliczenia liczby dni opóźnienia przez organ nakładający karę organ II stopnia, rozpatrujący sprawę ponownie, może zmienić wysokość kary na niekorzyść żalącego, jeśli stwierdzi, że postanowienie rażąco narusza prawo lub rażąco narusza interes publiczny, i - tym samym - podwyższyć karę za opóźnienie ${ }^{20}$.

Za represyjnym charakterem kary za niewydanie decyzji w terminie przemawia także moment jej nałożenia - organ zostanie obciążony karą dopiero po wydaniu decyzji u.1.i.c.p., czyli w momen-

18 Ibidem, s. 24.

19 Por. wyrok SO w Olsztynie z dnia 14 listopada 2016 r., IV Pa 142/16, http://orzeczenia.olsztyn.so.gov.pl (dostęp: 22.03.2019 r.).

20 Zob. wyrok WSA w Warszawie z dnia 23 kwietnia 2015 r., IV SA/Wa $187 / 15$, Legalis nr 1258039. 
cie, kiedy już załatwił sprawę, ponieważ dopiero wówczas staje się możliwe precyzyjne wyliczenie kary. Należy przypuszczać, że gdyby celem ustawodawcy była wyłącznie prewencja, to nie uzależniałby kary od liczby dni opóźnienia, ale określiłby ją w sposób „widełkowy", w trakcie zaś jej wymierzania zezwoliłby na stosowanie przez organ tzw. luzu decyzyjnego.

Charakter prawny kary pieniężnej za opóźnienie w wydaniu decyzji u.l.i.c.p. determinowany jest również przez formę działania administracji, w jakiej następuje jej wymierzenie. Analiza art. 1 pkt 1 k.p.a. prowadzi do wniosku, że postępowanie w sprawie wymierzenia organowi kary pieniężnej jest postępowaniem odrębnym, szczególnym, do którego nie mają zastosowania przepisy k.p.a. ${ }^{21}$ Owszem, nie jest to $z$ całą pewnością sprawa indywidualna, rozstrzygana w drodze decyzji administracyjnej. Ponadto między organem wydającym decyzję u.l.i.c.p. w I instancji a organem wyższego stopnia zachodzi stosunek wynikający $z$ hierarchicznej budowy organów administracji publicznej, nie zaś stosunek administracyjnoprawny, jaki istnieje pomiędzy inwestorem a organem administracji publicznej kompetentnym do wydania tej decyzji ${ }^{22}$. Przyjmuje się w związku z tym, że jest to kwestia raczej o charakterze procesowym, wynikająca $z$ toku postępowania, nie tworzy zaś odrębnej „sprawy administracyjnej" w znaczeniu materialnoprawnym ani odrębnego stosunku administracyjnoprawnego między organem wydającym decyzję u.1.i.c.p. a wojewodą. Istota art. 51 ust. 2 u.p.z.p. ma charakter procesowy, a jej celem jest przyspieszenie załatwienia sprawy ${ }^{23}$.

Powyższe stanowisko, wyrażone, jak zostało wskazane, zarówno w doktrynie, jak i orzecznictwie, nie jest jednak tak oczywiste, jak mogłoby się prima facie wydawać. W szczególności należy zasygnalizować brzmienie art. 1 pkt 5 k.p.a. ${ }^{24}$, który został wprowadzony

${ }^{21}$ Wyrok NSA z dnia 10 lipca 2009 r., II OSK 1118/08, Lex nr 552820.

${ }^{22}$ Zob. A. Despot-Mładanowicz, w: Ustawa o planowaniu i zagospodarowaniu przestrzennym. Komentarz aktualizowany, red. A. Plucińska-Filipowicz, M. Wierzbowski, Lex/el. 2019, komentarz do art. 51, uw. 4.

${ }^{23}$ Por. orzeczenie wydane na tle tożsamych regulacji w Pr. bud.: postanowienie NSA z dnia 30 września 2005 r., II OSK 989/05, Legalis nr 75639.

24 „Kodeks postępowania administracyjnego normuje nakładanie lub wymierzanie administracyjnych kar pieniężnych lub udzielanie ulg w ich wykonaniu”. 
do k.p.a. później ${ }^{25}$, niż zaczęły obowiązywać przepisy regulujące karę $z$ art. 51 ust. 2 u.p.z.p. Należy wobec powyższego rozważyć, czy aby na pewno przepisy regulujące karę za niewydanie decyzji u.l.i.c.p. są aktualne i dostosowane do stanu materialnoprawnej regulacji kar pieniężnych w k.p.a.

\section{Termin na wydanie decyzji a termin warunkujący nałożenie kary pieniężnej}

Zasady związane $z$ terminami, w jakich powinna zostać załatwiona sprawa, określają przepisy art. 12 oraz 35-36 k.p.a. Organy powinny, zgodnie $z$ zasadą szybkości i prostoty postępowania określoną w art. 12 k.p.a., działać w sprawie wnikliwie i szybko, posługując się możliwie najprostszymi środkami prowadzącymi do jej załatwienia, a sprawy, które nie wymagają zbierania dowodów, informacji lub wyjaśnień, powinny załatwiać niezwłocznie. W przypadku spraw wymagających postępowania wyjaśniającego regułą jest załatwianie spraw nie później niż w ciągu miesiąca, a spraw szczególnie skomplikowanych - nie później niż w ciągu dwóch miesięcy od dnia wszczęcia postępowania. Wydaje się, że w powyższych terminach powinna zostać również wydana decyzja u.l.i.c.p. Należy uznać, że podstawowych terminów załatwienia sprawy nie zmienia w tym przypadku regulacja art. 51 ust. 2 u.p.z.p. nakazująca organowi wyższego stopnia wymierzenie kary pieniężnej organowi, który nie wydał decyzji w terminie 65 dni od dnia złożenia wniosku ${ }^{26}$. Nie oznacza to bowiem, że organ „zyskuje” tym samym dodatkowy czas na rozpatrzenie sprawy. Przyjęcie odmiennego założenia oznacza-

25 Ustawa $z$ dnia 7 kwietnia 2017 r. o zmianie ustawy - Kodeks postępowania administracyjnego oraz niektórych innych ustaw (tekst jednolity: Dz.U. z 2017 r. poz. 935), która dodała nowy pkt 5 do art. 1, weszła w życie dopiero w dniu 1 czerwca 2017 r.

${ }^{26}$ Odmiennie A. Despot-Mładanowicz, który wskazuje, że art. 51 ust. 2 u.p.z.p. stanowi regulację odrębną od zawartej w art. 35 § 3 k.p.a., w związku z czym termin do wydania decyzji w sprawie ustalenia lokalizacji inwestycji celu publicznego wynosi 65 dni i jest liczony od dnia złożenia wniosku o wydanie takiej decyzji, zob. A. Despot-Mładanowicz, op.cit., komentarz do art. 51, uw. 4. 
łoby korzystniejsze dla organu ukształtowanie terminu załatwiania sprawy, co prowadziłoby do nieskutecznej ochrony interesu publicznego i interesu jednostki. Jak wskazuje Barbara Adamiak, „szybkość, tj. zasada osiągania końcowego celu postępowania administracyjnego w najkrótszym czasie, należy do kardynalnych zasad dobrego postępowania"27. Naruszeniem tej zasady byłoby niewątpliwie przyjęcie, że organ ma na załatwienie sprawy aż 65 dni i nie jest obowiązany sprawy załatwić niezwłocznie, w ciągu miesiąca, ostatecznie - dwóch miesięcy, co wciąż jest terminem krótszym niż przewidziany w art. 51 ust. 2 u.p.z.p.

Wskazanie okresu 65-dniowego nie jest wobec powyższego terminem załatwienia sprawy, a jedynie umożliwia uruchomienie innych niż określone w k.p.a. środków dyscyplinujących organ. Należy jednak wskazać, że karę nakłada się na organ już po zakończeniu postępowania i wydaniu decyzji u.l.i.c.p., natomiast zwykły środek zwalczania bezczynności czy przewlekłego prowadzenia postępowania przez organ, o którym mowa w art. 37 k.p.a., tj. ponaglenie, może zostać wniesiony w każdym czasie.

Obliczenie 65-dniowego terminu i ocena, czy organ mu uchybił, wymaga nie tylko zbadania, w jakiej dacie wpłynął wniosek i została wydana decyzja, ale również, czy odpowiedni czas został odliczony. Do terminu, o którym mowa w art. 51 ust. 2 u.p.z.p., nie wlicza się bowiem terminów przewidzianych w przepisach prawa do dokonania określonych czynności, okresów zawieszenia postępowania oraz okresów opóźnień spowodowanych z winy strony albo z przyczyn niezależnych od organu. Chodzi tutaj o uwzględnienie faktycznego, efektywnego czasu załatwiania sprawy przez organ ${ }^{28}$.

Bez wątpienia w ramach „dokonania określonych czynności” mieści się uzgadnianie decyzji u.l.i.c.p. Ich celem jest zapewnienie zgodności zamierzenia inwestycyjnego $z$ państwowym porządkiem prawnym $^{29}$. Zakres uzgodnienia decyzji, co wynika $z$ art. 53 ust. 4

27 B. Adamiak, w: B. Adamiak, J. Borkowski, Kodeks postępowania administracyjnego. Komentarz, Warszawa 2017, komentarz do art. 12, Nb 1.

${ }^{28}$ Por. R. Hauser, Terminy załatwiania spraw $w$ k.p.a. $w$ doktrynie i orzecznictwie sadowym, „Ruch Prawniczy, Ekonomiczny i Socjologiczny” 1997, nr 1, s. 5.

${ }^{29}$ A. Despot-Mładanowicz, op.cit., komentarz do art. 53, uw. 7. 
u.p.z.p., zależy przy tym od położenia terenu, który stanowi przedmiot analizy pod względem warunków i zasad zagospodarowania. Czas potrzebny na uzgodnienie powoduje opóźnienie, ale powstaje ono $z$ przyczyn niezależnych od organu administracji wydającego decyzję u.1.i.c.p. ${ }^{30}$ Jednakże należy wskazać, że obliczając okres opóźnienia w wydaniu decyzji u.l.i.c.p., organ nakładający karę pieniężną nie wliczy do niego okresu od daty nadania wniosku o dokonanie uzgodnienia projektu decyzji do daty doręczenia stanowiska organu uzgadniającego. W przypadku tzw. milczącego uzgodnienia - zgodnie $z$ brzmieniem art. 53 ust. 5 zdanie drugie u.p.z.p. - datą końcową będzie dzień, w którym upłyną 2 tygodnie (lub 21 dni - w przypadku regionalnego dyrektora ochrony środowiska, zob. art. 53 ust. 5c u.p.z.p.) od dnia doręczenia wystąpienia o uzgodnienie. W szczególności w kontekście milczącego uzgodnienia nie będzie miało znaczenia, kiedy dokładnie doręczono stanowisko organu współdziałającego organowi załatwiającemu sprawę, czy też - kiedy się ono uprawomocniło. Uchybienie dwutygodniowemu, materialnemu, zawitemu terminowi powoduje wystąpienie skutku uzgodnienia $z$ mocy prawa oraz wygaśnięcie kompetencji organu współdziałającego, przy czym skutek prawny uzgodnienia ma moc od dnia doręczenia wystąpienia o uzgodnienie ${ }^{31}$.

Do opóźnień spowodowanych $z$ winy strony $z$ całą pewnością zaliczyć należy okres, w którym organ wzywa do uzupełnienia braków formalnych i wyznacza termin na dokonanie czynności. Jednocześnie jednak sama ocena wniosku pod względem zachowania wymogów formalnych stanowi już zwykłą czynność procesową, która bezpośrednio zmierza do załatwienia sprawy, w związku z czym nie podlega odliczeniu od 65-dniowego terminu na wydanie

30 Por. wyrok NSA z dnia 14 grudnia 2017 r., II OSK 495/17, Legalis nr 1756674.

${ }^{31}$ Wyrok NSA z dnia 21 listopada 2017 r., II OSK 500/16, Legalis nr 1711066; por. M. Borowiak, Charakter terminów na uzgodnienie projektów decyzji lokalizacyjnych a możliwość wykonywania kompetencji przez organy ochrony przyrody, w: Prawne aspekty gospodarowania zasobami środowiska. Oddziaływanie na zasoby środowiska, red. B. Rakoczy, M. Szalewska, K. Karpus, Toruń 2014, s. 43 . 
decyzji ${ }^{32}$. Do czynności zwykłych, wiążących się z załatwieniem sprawy i normalnym tokiem postępowania, trzeba zakwalifikować także np. zawiadomienie stron o wszczęciu postępowania (art. 61 $\S 4$ k.p.a.), oczekiwanie organu na pismo, które nie ma wpływu na bieg sprawy, czy zasięganie porady organów nadrzędnych co do sposobu załatwienia sprawy ${ }^{33}$. Wśród czynności obligatoryjnych, a więc takich, których czas nie podlega odliczeniu, uwzględnia się również okres wywieszenia obwieszczenia o wszczęciu postępowania w sprawie ${ }^{34}$, zawiadamianie o przeprowadzaniu dowodu łącznie z udziałem w jego przeprowadzaniu (art. 79 k.p.a.) czy też zawiadamianie stron o możliwości wypowiedzenia się co do zebranych dowodów i materiałów oraz zgłoszonych żądań łącznie z czasem wyznaczonym na takie zapoznanie (art. $10 \S 1$ k.p.a.) ${ }^{35}$.

Stosowania art. $10 \S 1$ k.p.a. może jednakże budzić pewne wątpliwości. Organ jest obowiązany zapewnić stronom czynny udział w każdym stadium postępowania, a przed wydaniem decyzji umożliwić im wypowiedzenie się co do zebranych dowodów i materiałów oraz zgłoszonych żądań. Choć w przepisach k.p.a. nie wskazano terminu, w którym strona ma możliwość wypowiedzenia się i zapoznania $z$ aktami sprawy, okres ten powinien być na tyle długi, aby umożliwić stronie faktyczne skorzystanie $z$ uprawnień. Przyjmuje się, że termin określony do zapoznania się przez stronę z zebranym w sprawie materiałem dowodowym powinien być jednak terminem realnym ${ }^{36}$. W orzecznictwie uznaje się, że zbyt krótki jest nawet termin pięciodniowy na zapoznanie się $z$ aktami ${ }^{37}$.

${ }^{32}$ Wyrok WSA w Warszawie $z$ dnia 21 czerwca 2016 r., IV SA/Wa 1182/16, Lex nr 2137799.

${ }^{33}$ Wyrok NSA z 17 marca 1988 r., SAB/Gd 14/87, Orzecznictwo Naczelnego Sądu Administracyjnego 1988, nr 1, poz. 41.

${ }^{34}$ Wyrok WSA w Warszawie $z$ dnia 23 kwietnia 2015 r., IV SA/Wa 187/15, Legalis $\mathrm{nr} 1258039$.

${ }^{35}$ Wyrok WSA w Warszawie $z$ dnia 28 stycznia 2013 r., IV SA/Wa 1913/12, Lex nr 1326614.

36 Wyrok NSA z dnia 10 grudnia 1997 r., I SA/Gd 409/96, Legalis nr 41344.

37 Wyrok WSA w Warszawie $z$ dnia 19 marca 2015 r., VI SA/Wa 2512/14, Legalis $\mathrm{nr} 1765058$. 
Przyjęcie, że termin wyznaczony stronie na podstawie art. 10 $\S 1$ k.p.a. nie jest terminem przewidzianym w przepisach prawa do dokonania określonych czynności, o którym mowa w art. 51 ust. 2c u.p.z.p. ${ }^{38}$, może prowadzić do groźnego skracania przez organy czasu na zapoznanie się $z$ aktami i zgłoszenie uwag do absolutnego minimum, a więc do 2-3 dni. Owszem, trudno uznać, że czas potrzebny na wykonanie czynności związanych $z$ realizacją obowiązku organu administracji wynikającego $z$ art. $10 \S 1$ k.p.a. stanowi opóźnienie $z$ winy strony albo $z$ przyczyn niezależnych od organu. Czynności te powinny być podejmowane w każdym postępowaniu i nie są one zdarzeniami nadzwyczajnymi i niezależnymi od organu administracji ${ }^{39}$. Niemniej jednak terminy wyznaczane przez organ, a stanowiące swego rodzaju gwarancje procesowe, mogą być zagrożone w postępowaniu o wydanie decyzji u.l.i.c.p., co $z$ całą pewnością nie było zamysłem ustawodawcy wprowadzającego środki dyscyplinujące organ.

\section{Organ wyższego stopnia w sprawie wymierzenia kary pieniężnej}

Wskazanie adresata kary pieniężnej, o której mowa w art. 51 ust. 2 u.p.z.p., wydaje się nie nastręczać większych problemów. Ustawodawca dość jasno zakreśla krąg adresatów poprzez wskazanie w art. 51 ust. 1 u.p.z.p. organów wydających decyzję u.l.i.c.p. - organu wykonawczego gminy oraz wojewody. Równie jasno rozstrzyga, że to organ wyższego stopnia ma wymierzyć karę za niewydanie decyzji w terminie. Jako organ wyższego stopnia zaś wskazuje wojewodę (art. 51 ust. 2a u.p.z.p.), który swoje rozstrzygnięcie wydaje $\mathrm{w}$ formie postanowienia. Na postanowienie przysługuje zażalenie.

Wskazanie wojewody jako organu wyższego stopnia stanowi wyjątek od zasady określonej w art. 17 pkt 1 k.p.a., zgodnie z którym organem wyższego stopnia w stosunku do organów jednostek

${ }^{38}$ Wyrok NSA $z$ dnia 14 grudnia 2017 r., II OSK 495/17, Lex nr 2458504.

39 Wyrok NSA $z$ dnia 14 grudnia 2017 r., II OSK 1182/17, Lex nr 2458510; por. wyrok NSA z 19 maja 2016 r., II OSK 1842/15, Legalis nr 1485675. 
samorządu terytorialnego są samorządowe kolegia odwoławcze. Tak jednoznaczne wskazanie na wojewodę jako organ właściwy do wymierzenia kary jest co najmniej wątpliwe w kontekście decyzji o ustaleniu lokalizacji inwestycji celu publicznego na terenach zamkniętych wydawanych właśnie przez wojewodę. Ustawodawca nie wyłącza przepisu art. 51 ust. 1 pkt 3 u.p.z.p. z zakresu dyspozycji art. 51 ust. 2 u.p.z.p., co oznacza, że również wojewoda uchybiający terminowi do wydania decyzji u.l.i.c.p. w terminie winien uiścić karę pieniężną, którą nałoży - jak wynika $z$ regulacji ustawowej - sam na siebie. Przepis nie pozostawia wątpliwości co do tego, że kara musi zostać nałożona (nie działa tutaj organ w sferze uznania), a więc nie ma obaw co do faworyzowania wojewody przez samego siebie w sytuacji, gdy zwleka on $z$ wydaniem decyzji u.l.i.c.p. Niemniej sytuacja, gdy organ ma ukarać sam siebie, jest w praktyce co najmniej niepożądana.

Wobec powyższego powstaje pytanie, czy w takiej sytuacji - mimo wszystko - nie powinien zostać zastosowany przepis art. 17 pkt 2 k.p.a., wyznaczający ministra właściwego jako organ wyższego stopnia w stosunku do wojewody. $Z$ całą pewnością byłby to krok w kierunku zapewnienia efektywności i egzekwowalności kary. Mimo jednoznacznie zobowiązującego brzmienia przepisu art. 51 ust. 2 u.p.z.p. nie można bowiem wykluczyć, że wojewoda będzie próbował uniknąć nałożenia kary na samego siebie. Ma to uzasadnienie również w kontekście tego, że organem właściwym do rozpatrzenia zażalenia jest - w związku z brakiem szczególnych wskazań w u.p.z.p. - organ wyznaczony w oparciu o k.p.a., a więc właściwy minister. Skoro więc powinniśmy stosować k.p.a. w tej sytuacji, to dlaczego nie pójść krok dalej i nie stosować jej również przy wyznaczaniu organu wymierzającego karę wobec zwlekającego wojewody? $Z$ pewnością pomocne byłoby wprowadzenie wprost gwarancji ustawowych w tym zakresie i odesłanie do k.p.a., co też należy postulować de lege ferenda. Wówczas konsekwentnie na postanowienie w sprawie kary nałożonej na wojewodę powinno przysługiwać nie zażalenie, ale wniosek o ponowne rozpatrzenie sprawy skierowany do właściwego ministra (art. $144 \mathrm{w}$ zw. z art. 127 $\S 3$ k.p.a.). 


\section{5. „Przedawnienie” kary pieniężnej}

Ostatnie zmiany w art. 51 u.p.z.p. zostały wprowadzone niejako „przez okazji” wejścia w życie Ustawy z dnia 5 lipca 2018 r. o ułatwieniach w przygotowaniu i realizacji inwestycji mieszkaniowych oraz inwestycji towarzyszących ${ }^{40}$. Przepisem art. 49 u.u.p.r.i.m. dodano do art. 51 u.p.z.p. zupełnie nowy ust. 2 d dotyczący „swoistego rodzaju przedawnienia”, jak zostało to określone w uzasadnieniu do projektu specustawy mieszkaniowej ${ }^{41}$.

Zgodnie $z$ brzmieniem art. 51 ust. 2d u.p.z.p. kary pieniężnej za zwłokę nie wymierza się, a wszczęte postępowania w sprawie wymierzenia kary umarza się, jeżeli od dnia wydania decyzji w sprawie ustalenia lokalizacji inwestycji celu publicznego przez organ I instancji upłynęły 3 lata. Zdyscyplinowanie organu i wymuszenie na nim wydawania decyzji w terminie, stanowiące cel nakładania kary pieniężnej, o której mowa w art. 51 ust. 2 u.p.z.p., jest zasadne w okresie jej faktycznego wydawania, a wymierzanie kary po upływie kilku lat, gdy sprawa zapewne jest już zakończona, wydaje się bezzasadne ${ }^{42}$.

Wydanie decyzji u.1.i.c.p. rozpoczyna bieg trzyletniego materialnoprawnego, zawitego terminu przedawnienia kary pieniężnej. Należy przy tym zauważyć, że datą wydania przez organ decyzji jest data złożenia podpisu przez osobę upoważnioną do jej wydania. Przepisy k.p.a. nie dają podstaw do utożsamiania wydania decyzji z jej doręczeniem ${ }^{43}$. Oznacza to w pierwszej kolejności, że dla biegu terminu przedawnienia nie ma znaczenia, kiedy decyzja stała się ostateczna, jak również, że po upływie 3 lat nie ma podstawy mate-

${ }^{40}$ Dz.U. z 2018 r. poz. 1496 ze zm., dalej jako: u.u.p.r.i.m. lub specustawa mieszkaniowa.

${ }^{41}$ Uzasadnienie do projektu druk sejmowy nr 2667, s. 27, http://orka.sejm. gov.pl/Druki8ka.nsf/0/3C9E0F27C1558355C12582B900589B5F/\%24File /2667.pdf, (dostęp: 21.03.2019 r.).

${ }^{42}$ P. Nowakowski-Węgrzynowski, w: Specustawa mieszkaniowa, s. 490.

${ }^{43}$ Zob. M. Dyl, w: Kodeks postępowania administracyjnego. Komentarz, red. M. Wierzbowski, R. Hauser, Warszawa 2018, komentarz do art. 109, Nb 6. 
rialnoprawnej do nałożenia kary w drodze decyzji ${ }^{44}$. Termin zawity nie może być przywrócony lub przedłużony.

Jak wskazuje Przemysław Nowakowski-Węgrzynowski, określenie terminu wygaśnięcia obowiązku wymierzenia kary pieniężnej było w praktyce pożądane ${ }^{45}$. I choć nie można zaprzeczyć, że sam fakt uregulowania tej kwestii zasługuje na aprobatę, to sposób jej wprowadzenia i możliwe naruszenie przez ustawodawcę zasad prawidłowej legislacji budzi wątpliwości ${ }^{46}$.

\section{Podsumowanie}

W związku z przedłużającymi się postępowaniami w sprawach wydania decyzji o ustaleniu lokalizacji inwestycji celu publicznego, ustawodawca wprowadził do u.p.z.p. środek dyscyplinujący, w postaci kary pieniężnej w wysokości 500 zł za każdy dzień opóźnienia w wydaniu decyzji w terminie 65 dni od daty złożenia wniosku. Kara pieniężna za niewydanie decyzji u.l.i.c.p. w ustawowo określonym terminie nie jest $z$ całą pewnością typową administracyjną karą pieniężną. O jej nietypowości świadczy nie tylko brak rozstrzygnięcia w formie decyzji administracyjnej, nawiązanie stosunku bazującego na zasadzie hierarchiczności między organami czy też brak „sprawy” w rozumieniu art. 1 pkt 1 k.p.a. Kara wymierzana organowi w trybie art. 51 ust. 2 u.p.z.p. i nast. rządzi się bowiem własnym, określonym w u.p.z.p., reżimem procesowym, choć jed-

${ }^{44}$ Zob. Planowanie i zagospodarowanie przestrzenne, komentarz do art. 51, $\mathrm{Nb} 6$.

45 Por. P. Nowakowski-Węgrzynowski, op.cit., s. 490.

${ }^{46}$ Chodzi o potencjalne naruszenie $\S 92$ ust. 1 załącznika do Rozporządzenia Prezesa Rady Ministrów z dnia 20 czerwca 2002 r. w sprawie „Zasad techniki prawodawczej” (tekst jednolity: Dz.U. z 2016 r. poz. 283 ze zm.), jedną ustawą zmieniającą obejmuje się tylko jedną ustawę, a odstępstwo od tej zasady (ust. 2) jest dopuszczalne tylko w dwóch przypadkach: gdy między zmienianymi ustawami występują niewątpliwe związki tematyczne lub gdy do zrealizowania zamysłu prawodawcy jest niezbędne jednoczesne dokonanie zmian w kilku ustawach. Zasada ta została w u.u.p.r.i.m. naruszona wielokrotnie; por. K. Rokicka-Murszewska, w: Specustawa mieszkaniowa, s. 470-471, 481. 
nocześnie w pewnym zakresie istnieje również konieczność zastosowania przepisów k.p.a. Wyznaczanie organu wyższego stopnia czy też wnoszenie środków zaskarżenia od postanowienia w sprawie kary nie może odbywać się w oderwaniu do przepisów normujących ogólne postępowanie administracyjne.

Ponadto procedura wymierzania kary nie może w żaden sposób naruszać praw i gwarancji inwestora w postępowaniu administracyjnym, w szczególności na tle terminów załatwienia sprawy. Upływ 65-dniowego terminu nie pozbawia inwestora możliwości wniesienia środków dyscyplinujących określonych w k.p.a. Wydaje się również, że nie dochodzi do zmiany terminów załatwienia sprawy. Jednocześnie jednak na tle obliczania 65-dniowego terminu na wydanie decyzji istnieje sporo rozbieżności interpretacyjnych. Należy postulować doprecyzowanie, choć niewątpliwie jest to zadanie trudne, jakich dokładnie czynności i okresów ich wykonywania nie wlicza się do przedmiotowego terminu. Dzięki temu będzie można uniknąć celowego skracania przez organ terminów przezeń wyznaczanych stronie wyłącznie w celu uniknięcia stosunkowo dotkliwej kary pieniężnej.

Jeśli chodzi o charakter prawny kary, to z całą pewnością należy wskazać, że jest to środek dyscyplinujący organ do szybszego procedowania, a jego głównym celem jest usprawnienie procesu inwestycyjnego. Jej wysokość i sposób obliczania, jak również brak możliwości zastosowania uznania przez organ, który ją wymierza, zdają się potwierdzać represyjno-prewencyjny charakter kary.

\section{STRESZCZENIE}

Kara pieniężna za niewydanie decyzji o ustaleniu lokalizacji inwestycji celu publicznego w ustawowym terminie wybrane problemy

Celem artykułu jest analiza problemów związanych z karą pieniężną za niewydanie decyzji o ustaleniu lokalizacji inwestycji celu publicznego w ustawowym terminie. W szczególności istotną kwestią w kontekście przedmiotowej kary był jej charakter prawny, determinujący drugi istotny problem - terminy załatwienia sprawy i związek pomiędzy karą a gwaran- 
cjami procesowymi dla jednostki w postępowaniu w sprawie wydania decyzji o ustaleniu lokalizacji inwestycji celu publicznego. Autorka sygnalizuje możliwe problemy, jakie mogą się pojawić w toku postępowania w sprawie wydania decyzji i następującego po nim - potencjalnego - procesu nakładania kary pieniężnej. Przeprowadzona analiza stała się również podstawą do wysunięcia postulatów zmian w u.p.z.p.

Słowa kluczowe: kara pieniężna; decyzja o ustaleniu lokalizacji inwestycji celu publicznego; inwestycja celu publicznego; kara administracyjna; sankcja administracyjna

\section{SUMMARY}

Penalty payment for failure to decide on establishing the location of public purpose investment within the statutory deadline selected issues

The aim of this article is to analyze problems related to penalty payment for failure to decide on establishing the location of public purpose investment within the statutory deadline. In particular, an important issue in the context of this penalty concerned was its legal nature, determining the second problem - time-limit to dispose of a matter and the relationship between the penalty payment and guarantees for protection of the individual in the proceedings in matters involving decision on establishing the location of public purpose investment. The author signals possible problems that may occur in the procedure for the issue of a decision and imposition of a penalty payment. The conducted analysis became the basis for the de lege ferenda postulates in the Act on Spatial Planning and Land Development from 2003.

Keywords: penalty payment; decision on establishing the location of public purpose investment; investment of a public purpose; administrative penalty; administrative sanction

\section{BIBLIOGRAFIA}

Adamiak B., Borkowski J., Kodeks postępowania administracyjnego. Komentarz, Warszawa 2017.

Borowiak M., Charakter terminów na uzgodnienie projektów decyzji lokalizacyjnych a możliwość wykonywania kompetencji przez organy ochrony 
przyrody, w: Prawne aspekty gospodarowania zasobami środowiska. Oddziaływanie na zasoby środowiska, red. B. Rakoczy, M. Szalewska, K. Karpus, Toruń 2014.

Hauser R., Terminy załatwiania spraw $w$ k.p.a. $w$ doktrynie i orzecznictwie sadowym, „Ruch Prawniczy, Ekonomiczny i Socjologiczny” 1997, nr 1. Kodeks postępowania administracyjnego. Komentarz, red. M. Wierzbowski, R. Hauser, Warszawa 2018.

Kosicki A., Kara za nieterminowe wydanie pozwolenia na budowę, „Nieruchomości” 2011 nr 3, dodatek: „Prawo Budowlane w Orzecznictwie Sądów Administracyjnych".

Nowicki H., Sankcje administracyjne, w: System prawa administracyjnego, tom 7: Prawo administracyjne materialne, red. R. Hauser, Z. Niewiadomski, A. Wróbel, Warszawa 2012.

Planowanie i zagospodarowanie przestrzenne. Komentarz, red. Z. Niewiadomski, Warszawa 2018.

Plucińska-Filipowicz A., Kara za zwłokę $w$ wydaniu pozwolenia na budowę, „Nieruchomości” 2011 nr 3, dodatek: „Prawo Budowlane w Orzecznictwie Sądów Administracyjnych".

Rokicka K., Uchwały rady gminy $w$ procedurze planistycznej - wybrane problemy, „Samorząd Terytorialny” 2015, nr 11.

Rokicka-Murszewska K., Administracyjnoprawne aspekty opłaty planistycznej, Toruń 2019.

Specustawa mieszkaniowa. Komentarz, red. A. Jakubowski, Warszawa 2019.

Ustawa o planowaniu i zagospodarowaniu przestrzennym. Komentarz aktualizowany, red. A. Plucińska-Filipowicz, M. Wierzbowski, Lex/el. 2019.

Wincenciak M., Sankcje $w$ prawie administracyjnym i procedura ich wymierzania, Warszawa 2008. 